\title{
SUBCLINICAL HYPOTHYROIDISM IN PREGNANCY; IS THERE A NEED FOR PHARMACOLOGICAL INTERVENTION?
}

\author{
SHRIPAD HEBBAR ${ }^{1 *}$, SAHAN KUMAR ${ }^{1}$, SAPNA AMIN ${ }^{1}$, SNEHA DOIZODE ${ }^{1}$ \\ Department of Obstetrics and Gynaecology, Kasturba Medical College, Manipal University, Manipal, Karnataka 576102 \\ Email: shripad.hebbar@manipal.edu
}

Received: 10 Dec 2016 Revised and Accepted: 17 Jan 2017

\section{ABSTRACT}

Objective: To find the prevalence of subclinical hypothyroidism in the first trimester of pregnancy and to compare the maternal and perinatal outcome in them with euthyroid mothers.

Methods: The present study was a prospective observational case-control study done in a tertiary hospital over the period of one and half years. Pregnant women in the first trimester of pregnancy were tested for Thyroid Stimulating Hormone (TSH) levels and those who had TSH $>2.5 \mathrm{mIU} / \mathrm{l}$, free T3 and free T4 estimation was carried out on the same sample. A total of 171 women could be followed up till delivery and their first-trimester thyroid profile was available for analysis. They were grouped into two groups, Group 1: all women with TSH level>2.5 mIU/l, considered to be hypothyroid ( $\mathrm{n}=79$ ), Group 2: women with euthyroid status with TSH levels 0.1 to $2.5 \mathrm{mIU} / \mathrm{l}(\mathrm{n}=95)$. All the neonates delivered in the first group had cord blood TSH estimation.

Results: In the study period, there were 2632 deliveries. The number of pregnant women with first trimester TSH levels $>2.5$ mIU/l were 79 , giving the prevalence rate of $3 \%$ for subclinical hypothyroidism during pregnancy. The obstetric complications observed were gestational hypertension $3.8 \%$, gestational diabetes $6.3 \%$, placenta praevia $1.3 \%$ and preterm delivery $7.6 \%$. The perinatal complications included Intrauterine growth restriction (IUGR) 1.3\%, Low Birth Weight (LBW) 3.8\%, perinatal asphyxia 2.5\% and neonatal hypothyroidism $1.3 \%$. Only preterm delivery appeared to be significantly associated with subclinical hypothyroidism.

Conclusion: The observed complication rates were much similar, in fact, lesser with gestational diabetes, pregnancy hypertension, IUGR, LBW compared to global and Indian prevalence rates. This indicates that the cut-off for diagnosing subclinical hypothyroidism should be derived from TSH assays from the local geographic population and should guide the treating physician to establish appropriate TSH ranges where definite therapeutic intervention is required to improve the maternal and foetal outcome.

Keywords: Thyroid hormones, Subclinical hypothyroidism, Pregnancy complications, Levothyroxine

(c) 2016 The Authors. Published by Innovare Academic Sciences Pvt Ltd. This is an open access article under the CC BY license (http://creativecommons.org/licenses/by/4. 0/) DOI: http://dx.doi.org/10.22159/ijpps.2017v9i3.16542

\section{INTRODUCTION}

After diabetes, hypertension and anaemia, thyroid dysfunction constitutes for the majority of medical disorders in pregnancy. Among maternal thyroid disorders, hypothyroidism $(2.5 \%)$ is more prevalent than hyperthyroidism (1 to $0.4 \%$ ) [1]. There is a significant change in thyroid hormone metabolism in pregnancy. In a woman with poor thyroid reserve, thyroid deficient state occurs due to increased urinary loss of thyroxine due to increase in glomerular filtration rate (GFR) and placental transfer of thyroxin to the growing fetus. Hence, there is increased requirement for thyroid hormone during pregnancy (one and half times) and in the first trimester of pregnancy, fetus depends upon placentally transferred maternal thyroxin for its neuronal development, deficiency of which can result in mental retardation and cretinism [2]. Untreated mothers also can develop abortions, preeclampsia, abruptio placenta and preterm labour [3]. The effects on the baby include intrauterine growth restriction, intrauterine death, problems due to prematurity, increased admission rates to NICU [4]. Congenital hypothyroidism is known to occur more often in women with hypothyroidism in pregnancy and has a greater impact in the cognitive and scholastic performance of the child in future $[5,6]$.

There is no doubt that thyroxine replacement therapy for mothers with overt hypothyroidism (high TSH levels and low serum T4 concentration) improves maternal and foetal outcome. However same is controversial with subclinical hypothyroidism, where only TSH value is higher, but the thyroid hormones (T3 and T4) are within physiological range. Available evidence lacks potential benefits of thyroxine to reduce obstetric and neonatal complications in this special cohort of biochemical diagnosis of hypothyroidism without any symptoms of thyroid deficiency and supplementing them with thyroid medication simply may "medicalise" women with an intervention which should have been otherwise not necessary.

This prospective case-control study was carried out with an objective to find the prevalence rate of subclinical hypothyroidism in the first trimester of pregnancy and its implication on maternalfetal-neonatal outcome in comparison to a cohort of pregnant women with normal thyroid status.

\section{MATERIALS AND METHODS}

The present study was a prospective observational case-control study done in the Department of Obstetrics and Gynaecology, Kasturba Medical Hospital which is a tertiary care center of Kasturba Medical College, Manipal serving more than 20 lakh population of surround districts. The study period extended between Jan 2015 to June 2016. Women with a singleton pregnancy who had firsttrimester thyroid function tests were the target population. The duration of pregnancy was calculated from the date of last menstrual period (LMP) and cross verified with their first-trimester CRL values. Women with multifoetal gestation threatened and missed abortion, preexisting known medical disorders such as chronic hypertension, thyroid disorders were excluded from the study. All individuals signed informed consent prior to their enrollment in the study. The study complied with the Declaration of Helsinki and Departmental Scientific Committee gave permission to conduct the study after verifying local biomedical research regulations.

The venous blood of participating woman was collected in fasting status. The sample was sent to the main laboratory within $30 \mathrm{~min}$ of obtaining the sample. The serum was analysed for thyroid parameters (TSH initially and Free T3 and Free T4 if TSH was found 
to be $>2.5 \mathrm{mIU} / \mathrm{l}$ ) using COBAS 6000 system. Similarly, cord blood TSH was estimated only when maternal TSH was in the higher range.

A total of 171 women could be followed up till delivery and their first-trimester thyroid profile was available for analysis. They were grouped into two groups, Group 1: all women with TSH level $>2.5$ mIU/l, considered to be hypothyroid $(\mathrm{n}=79)$, Group 2: women with euthyroid status with TSH levels 0.1 to $2.5 \mathrm{mIU} / \mathrm{l}(\mathrm{n}=95)$. We used a cut-off value for TSH levels as $2.5 \mathrm{mIU} / \mathrm{l}$ to differentiate between hypo and euthyroid status according to the guidelines established by American Thyroid Association for the diagnosis and management of thyroid disease during pregnancy and postpartum [7].

Statistical analysis was done using Statistical Package for Social Sciences (SPSS) for Windows (Version 16.0. Chicago, SPSS Inc.). Descriptive statistics included estimation of mean, standard deviation and range (minimum to maximum values). Histogram and normal curve feature of SPSS software is used to display data distribution graphically. Student T-test was used to test the statistical significance of different means and standard deviation of numerical data. Similarly, Chi square test was used for categorical data. A p value of $<0.05$ was considered to be significant. Obstetrical complications were visually presented by using graph feature of Microsoft excel.

\section{Sample size estimation}

A study reported in Indian Journal of Clinical Biochemistry showed that the first-trimester mean \pm standard deviation of measured TSH levels is $1.71 \pm 1.38 \mathrm{mIU} / \mathrm{l}$ [8]. We decided that if the mean value exceeds $2.5 \mathrm{mIU} / \mathrm{l}$ (upper range for thyroid stimulating hormone in the first trimester) of sampled population, then it will be significantly different from the normal population. Accordingly, we estimated sample size to show the desired level of power of $90 \%$ and level of significance 0.05 , by using the formula,

$$
\mathrm{N}=[(\mathrm{z} \alpha+\mathrm{z} \beta) \sigma /(\mu 1-\mu 2)]^{2}
$$

Where $z \alpha=1.96$ (critical value that divides the central $95 \%$ of $z$ distribution from $5 \%$ in the tails), $z \beta=1.28$ (critical value that separates the lower $10 \%$ of distribution from upper $90 \%), \sigma=$ standard deviation (1.38), $\mu 1-\mu 2=$ difference of two means $(2.5-1.71$ $=0.79$ ).

Accordingly, it was estimated that 32 patients are required, and our present sample size of 79 patients is more than adequate to prove the hypothesis.

\section{RESULTS}

In the study period, there were 2632 deliveries. The number of pregnant women with first trimester TSH levels $>2.5 \mathrm{mIU} / \mathrm{l}$ were 79 (Group I) giving the prevalence rate of $3 \%$ for hypothyroidism during pregnancy. We used $2.5 \mathrm{mIU} / \mathrm{l}$ as a cut-off, as this is now universally accepted standard and approved by American Thyroid Association for thyroid disease [7].

Initially we performed only TSH levels in first trimmest of pregnancy and only when its level crossed the cut off, women were further subjected for free T3 and free T4 estimation (total T3 and total T4 were not considered as their level vary significantly in the first trimester because of physiological stimulation of thyroid glands by human chorionic gonadotrophin which is elevated in the first trimester of pregnancy). Hence in the level of free thyroxine in serum is a better predictor thyroid status rather than total thyroxine [9].

Table 1 shows complete thyroid profile of women diagnosed to have hypothyroidism in pregnancy.

Table 1: Thyroid profile of pregnant hypothyroid women $(n=79)$

\begin{tabular}{llll}
\hline Serum biochemistry & mean \pm SD & Minimum value & Maximum value \\
\hline TSHmU/l & $5.14 \pm 1.14$ & 2.90 & 8.23 \\
Free T3picomole/l & $4.51 \pm 0.70$ & 3.42 & 6.62 \\
Free T4picomole/l & $15.33 \pm 1.79$ & 11.45 & 20.68 \\
SD: Standard Deviation & & & \\
\hline
\end{tabular}

Table 2 shows the demographic parameters. From this table, it can be inferred that hypothyroid pregnant women likely deliver earlier than euthyroid women and also their newborn will weigh lower compared to normal population.

Table 2: Maternal characteristics

\begin{tabular}{lll}
\hline Demographic parameter & Cases (n=79) & Controls (n=95) \\
\hline Age in years (mean \pm SD) & $27.5 \pm 3.6$ & $28.3 \pm 3.2$ \\
Primigravida & 43 & 55 \\
Multigravida & 36 & 40 \\
Gestational Age at delivery (weeks) & $38.4 \pm 1.1$ & $39.0 \pm 0.09$ \\
Mean Birth Weight in Kg (mean \pm SD) & $3.03 \pm 0.36$ & $3.27 \pm 0.29$ \\
\hline
\end{tabular}

SD: Standard Deviation, NS: Not Significant, S: Significant, HS: Highly Significant

Table 3 shows maternal outcomes such as gestational hypertension (blood pressure $>140 / 90 \mathrm{mmHg}$ in absence of proteinuria and any imminent symptoms of eclampsia and normal lab parameters), gestational diabetes (defined as any one value abnormal with standard WHO 75 grams oral glucose tolerance test), placental praevia (diagnosed by antenatal ultrasound) and preterm birth (delivery at gestational age less than 37 completed weeks) in cases and control. From table 3 and fig. 1, it can be seen that mothers with hypothyroidism had significantly higher rate of preterm delivery compared to euthyroid mothers.

Table 3: Pregnancy outcome

\begin{tabular}{lll}
\hline Obstetric complication & Cases (n=79) & Controls (n=95) \\
\hline Gestational Hypertension & $3(3.8 \%)$ & $4(4.2 \%)$ \\
Gestational Diabetes & $5(6.3 \%)$ & $2(2.1 \%)$ \\
Placenta Praevia & $1(1.3 \%)$ & $0(0 \%)$ \\
Preterm Delivery & $6(7.6 \%)$ & $1(1.1 \%)$ \\
\hline
\end{tabular}

$P$ value of $<0.05$ is considered significant 


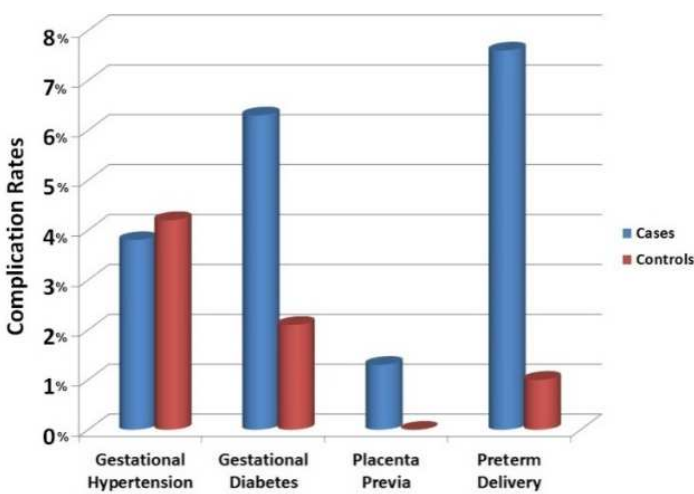

Fig. 1: Obstetric complication rates in cases and controls
Table 4 shows perinatal outcome in cases and controls. Intrauterine growth restriction was considered to be present when the expected fetal weight fell below $10^{\text {th }}$ centile for the corresponding gestational age. We defined low birth weight as neonatal weight less than $2.5 \mathrm{~kg}$. Perinatal hypoxia was said to exist when APGAR at 5 min was less than 3, need for assisted ventilation and admission to intensive neonatal care unit. There was one case of neonatal hypothyroidism in the hypothyroid group (cord blood TSH $>20 \mathrm{mIU} / \mathrm{l}$ ), however, the baby did not have serious complications and was discharged in time. Finally, the analysis showed that there was no significant difference between various perinatal outcomes in both the groups.

Table 5 shows the results of cord blood TSH levels in 79 hypothyroid mothers. There was one neonate whose cord blood TSH was $>20$ $\mathrm{mIU} / \mathrm{l}$. However neonatal T3 and T4 were within the normal range on the first and fourth day of life and baby was discharged with advice for regular follow up.

Table 4: Perinatal outcome

\begin{tabular}{lll}
\hline Perinatal complication & Cases (n=79) & Controls (n=95) \\
\hline Intrauterine growth restriction & $1(1.3 \%)$ & $2(2.1 \%)$ \\
Low Birth Weight & $3(3.8 \%)$ & $4(4.2 \%)$ \\
Perinatal Asphyxia & $2(2.5 \%)$ & $2(2.1 \%)$ \\
Neonatal Hypothyroidism & $1(1.3 \%)$ & 0.67 \\
P value of<0.05 is considered significant. & & 0.89 \\
\hline
\end{tabular}

Table 5: Descriptive statistics of cord blood TSH levels (mIU/l) in 79 newborn babies

\begin{tabular}{ll}
\hline Mean & 7.98 \\
Median & 7.39 \\
Std. Deviation & 3.77 \\
Range & $1.28-21.0$ \\
Percentiles & \\
$10^{\text {th }}$ Centile & 3.02 \\
$50^{\text {th }}$ Centile & 7.39 \\
$90^{\text {th }}$ Centile & 12.85 \\
\hline
\end{tabular}

Fig. 2 shows the histogram of cord blood TSH indicating that a good number of newborns had TSH levels on either side of the mean. This means that if cut off value for neonatal TSH level is lowered, the number of babies to be screened for neonatal hypothyroidism increases.

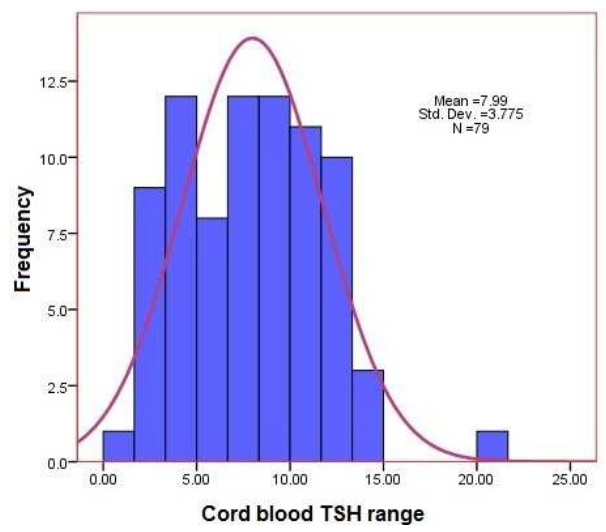

Fig. 2: Cord blood TSH levels in 79 newborns

\section{DISCUSSION}

There is a wide geographical variation of prevalence of hypothyroidism ranging between 0.3 to $0.5 \%$ in western countries, more so in developing countries like India. Even in India the prevalence rate varies across different states, as many of rural population suffer from dietary iodine deficiency, further aggravated by the presence of goitrogens in the diet, micronutrient deficiency such as selenium and others $[10,11]$. Pre-existing thyroid hormone deficiency is further aggravated during pregnancy as thyroid hormone requirements are increased during gestation not only by the mother but also by the growing foetus. In addition, there is increased renal clearance of iodide [12]. Therefore, it is very important to screen expectant mothers for thyroid deficiency, though the routine investigations during the antenatal period does not include thyroid panel.

Estimation of TSH is the primary screening tool, but its levels are affected by HCG hormone (human Chorionic Gonadotrophin). Because of its alpha chain similarity with TSH, hCG has a weak stimulatory effect on the maternal thyroid gland, making it to enlarge physiologically and produce more thyroxine [13]. The net effect is suppression of TSH levels and hence a different cut off is required to make the diagnosis of hypothyroidism in pregnancy.

The reference ranges for thyroid hormone profile varies from laboratory to laboratory. If laboratory specific trimester ranges are not available, it is desirable to follow Regulation 14.2 of ATA (American Thyroid Association for the Diagnosis and Management of Thyroid Disease during Pregnancy and Postpartum) guidelines, which give the reference values for the euthyroid state during pregnancy (table 6) [7].

In our 79 cases, first trimester TSH level was higher than the recommended cut-off of $2.5 \mathrm{mIU} / \mathrm{l}$, thereby substantiating the diagnosis of maternal hypothyroidism. As from table 1, when individual free T4 levels were looked into, none of them had low fT4 levels (cut-off 10.3 picomole/l) and this implies that all of our cases were belonging to the category of subclinical hypothyroidism. After consultation with thyroid physician, it was decided not to start them on any thyroxine replacement as their T3 and T4 levels were within 
acceptable limits. However, all of them were advised to consume iodized salt for cooking. Even WHO recommends daily iodine intake of $250 \mu \mathrm{g}$ iodine for pregnant women, which is considerably higher than the recommended $150 \mu$ g per day for general non-pregnant population [14]. Currently, the role of therapy with levothyroxine in subclinical hypothyroidism is controversial. According to Cochrane 2013 review, probably, the only indication to start thyroxine therapy is those cases of subclinical hypothyroidism with Anti-Thyroid Antibody positive status to improve health outcomes [15].

Table 6: Ranges of normal thyroid functions during pregnancy

\begin{tabular}{|c|c|c|c|}
\hline Thyroid profile & First trimester & Second trimester & Third trimester \\
\hline 1. TSH & 0.1 to $2.5 \mathrm{mIU} / \mathrm{l}$ & 0.2 to $3.0 \mathrm{mIU} / \mathrm{l}$ & 0.3 to $3.0 \mathrm{mIU} / \mathrm{l}$ \\
\hline 2. Free $\mathrm{T} 4$ & 0.8 to $1.2 \mathrm{ng} / \mathrm{dl}$ & 0.6 to $1 \mathrm{ng} / \mathrm{dl}$ & 0.5 to $0.8 \mathrm{ng} / \mathrm{dl}$ \\
\hline \multirow[t]{2}{*}{ Equivalent other Units } & 8 to $12 \mathrm{ng} / \mathrm{l}$ & 6 to $10 \mathrm{ng} / \mathrm{l}$ & 5 to $8 \mathrm{ng} / \mathrm{l}$ \\
\hline & 10.3 to $15.5 \mathrm{pm} / \mathrm{l}$ & 7.7 to $12.9 \mathrm{pm} / \mathrm{l}$ & 6.5 to $10.3 \mathrm{pm} / \mathrm{l}$ \\
\hline 3. Free T3 & 4.1 to $4.4 \mathrm{pg} / \mathrm{ml}$ & 4 to $4.2 \mathrm{pg} / \mathrm{ml}$ & Not Reported \\
\hline \multirow[t]{2}{*}{ Equivalent other Units } & 4.1 to $4.4 \mathrm{ng} / \mathrm{l}$ & 4 to $4.2 \mathrm{ng} / \mathrm{l}$ & Not Reported \\
\hline & 6.3 to $6.8 \mathrm{pm} / \mathrm{l}$ & 6.2 to $6.5 \mathrm{pm} / \mathrm{l}$ & Not Reported \\
\hline 4. Total T4 & 6.5 to $10.1 \mathrm{mcg} / \mathrm{dl}$ & 7.5 to $10.3 \mathrm{mcg} / \mathrm{dl}$ & 6.3 to $9.7 \mathrm{mcg} / \mathrm{dl}$ \\
\hline 5. Total T3 & 97 to $149 \mathrm{ng} / \mathrm{dl}$ & 117 to $169 \mathrm{ng} / \mathrm{dl}$ & 123 to $162 \mathrm{ng} / \mathrm{dl}$ \\
\hline
\end{tabular}

mIU/l: micro international unit per liter, ng/dl: nanogram per deciliter, pm/l: picomole per liter, mcg/dl: microgram per deciliter

Table 7: Prevalence and maternal-foetal outcome in various Indian Studies

\begin{tabular}{|c|c|c|c|c|c|}
\hline Author & $\begin{array}{l}\text { Year of } \\
\text { Study }\end{array}$ & $\begin{array}{l}\text { Place of } \\
\text { Study }\end{array}$ & $\begin{array}{l}\text { Prevalence of } \\
\text { Hypothyroidism }\end{array}$ & Obstetric and perinatal outcome & Reference \\
\hline Ajmani SN et al. & 2014 & New Delhi & $\begin{array}{l}48 \text { with hypothyroidism out } \\
\text { of } 400 \text { women }(12 \%)\end{array}$ & $\begin{array}{l}\text { Maternal: Anemia (12.5\%), Preeclampsia (10\%), } \\
\text { Abruption (4.2\%), GDM (2.1\%), PPH (6.3\%) } \\
\text { Foetal: IUGR (41.7\%), LBW (16.7\%), Foetal Distress } \\
(10.4 \%)\end{array}$ & [29] \\
\hline Aggarwal N et al. & 2014 & Chandigarh & $\begin{array}{l}197 \text { with hypothyroidism out } \\
\text { of } 1791 \text { women }(10.9 \%)\end{array}$ & $\begin{array}{l}\text { Maternal: PROM (4\%), Hypertension (12\%), GDM } \\
(2 \%) \text {, Preterm labour (16\%), Abruption }(1 \%) \\
\text { Foetal: SGA (16\%), Jaundice (14\%), RDS (1.5\%) }\end{array}$ & {$[30]$} \\
\hline $\begin{array}{l}\text { Pavanaganga et } \\
\text { al. }\end{array}$ & 2015 & Bangalore & $\begin{array}{l}168 \text { with hypothyroidism out } \\
\text { of } 1663 \text { women }(10.1 \%)\end{array}$ & $\begin{array}{l}\text { Maternal: Pre-eclampsia (21.8\%), GDM }(6.4 \%) \text {, } \\
\text { Preterm labor }(7.1 \%) \text { and anemia }(5.8 \%) \\
\text { Foetal: IUGR }(7.7 \%), \text { SGA }(14.7 \%), \text { IUD }(3.3 \%)\end{array}$ & {$[31]$} \\
\hline Singh A et al. & 2015 & Telangana & $\begin{array}{l}30 \text { with hypothyroidism out } \\
\text { of } 400 \text { women }(7.5 \%)\end{array}$ & $\begin{array}{l}\text { Maternal: Miscarriage (6.7\%), Anemia (10\%), } \\
\text { Preeclampsia (33.3\%), Preterm labor (3.3\%), PPH } \\
(3.3 \%) \\
\text { Foetal: IUGR (16.7\%) }\end{array}$ & {$[32]$} \\
\hline Kalpesh K et al. & 2015 & Ahmedabad & $\begin{array}{l}46 \text { with hypothyroidism out } \\
\text { of } 350 \text { women }(13.1 \%)\end{array}$ & $\begin{array}{l}\text { Maternal: Preterm (26\%), Anemia ( } 21.7 \%) \text {, } \\
\text { Preeclampsia (10.8\%), Abruption (2.1\%), GDM } \\
(8.6 \%) \text {, and PPH }(10.8 \%) \\
\text { Foetal: IUGR (6.5\%), LBW (34.7\%), Stillbirth }(2.1 \%)\end{array}$ & {$[33]$} \\
\hline Nirmala C et al. & 2015 & Trivandrum & 78 cases and 78 controls & $\begin{array}{l}\text { Maternal: Abortion }(23.1 \%) \text {, Gestational } \\
\text { Hypertension }(35.9 \%) \text {, PPH }(12.8 \%) \text {, Preterm } \\
\text { Delivery }(25.6 \%) \\
\text { Foetal: LBW }(28.2 \%) \text {, }\end{array}$ & {$[34]$} \\
\hline $\begin{array}{l}\text { Sreelakshmi U } \\
\text { et al. }\end{array}$ & 2015 & Bangalore & $\begin{array}{l}101 \text { with hypothyroidism out } \\
\text { of } 4864 \text { women }(2.07 \%)\end{array}$ & $\begin{array}{l}\text { Maternal: Threatened abortion (44.6\%), preterm } \\
\text { delivery }(24.8 \%) \\
\text { Foetal: IUGR (5\%), IUD (15\%) }\end{array}$ & [35] \\
\hline Nath J et al. & 2015 & Moradabad & $\begin{array}{l}60 \text { with hypothyroidism out } \\
\text { of } 1000 \text { women }(6 \%)\end{array}$ & $\begin{array}{l}\text { Maternal: Abortion (4.5\%), Preeclampsia (7.8\%), } \\
\text { Abruption (2.3\%), Preterm (2\%), PPH (1.\%) } \\
\text { Foetal: Prematurity (2\%), LBW (2/4\%), IUGR } \\
(1.8 \%) \text {, Stillbirth }(0.9 \%) \text {, neonatal Sepsis(1.5\%) }\end{array}$ & [36] \\
\hline Saraladevi et al. & 2016 & Warrangal & $\begin{array}{l}116 \text { with hypothyroidism out } \\
\text { of } 1000 \text { women }(11.6 \%)\end{array}$ & $\begin{array}{l}\text { Maternal: Preeclampsia 9.37\%, Preterm delivery } \\
7.81 \% \text {, Abortions } 4.68 \% \text {, Abruptio placenta } 1.56 \% \\
\text { Foetal: IUGR 6.25\%,Low birth weight } 4.68 \% \text {, Still } \\
\text { birth } 1.56 \%\end{array}$ & {$[37]$} \\
\hline Patwari M et al. & 2016 & Assam & 75 cases and 75 controls & $\begin{array}{l}\text { Significantly higher caesarean rates ( } 48 \%) \text {, low birth } \\
\text { weight ( } 500 \text { grams less), higher incidence of birth } \\
\text { asphyxia ( } 30.4 \%) \text {. }\end{array}$ & {$[38]$} \\
\hline $\begin{array}{l}\text { Chunchaiah S et } \\
\text { al. }\end{array}$ & 2016 & Bangalore & $\begin{array}{l}81 \text { with hypothyroidism out } \\
\text { of } 800 \text { women }(10.1 \%)\end{array}$ & $\begin{array}{l}\text { Maternal: Abortion (11.9\%), Preeclampsia }(13.6) \% \text {, } \\
\text { GDM (8.5\%), Anemia (8.4\%), Preterm labour }(5 \%) \\
\text { Foetal: IUGR (3.8\%), Still birth }(1.7 \%)\end{array}$ & [39] \\
\hline Patel RD et al. & 2016 & Ahmedabad & $\begin{array}{l}40 \text { with hypothyroidism out } \\
\text { of } 500 \text { women }(8 \%)\end{array}$ & $\begin{array}{l}\text { Maternal: Abortion (7.5\%), Preeclampsia }(10 \% \text {, } \\
\text { GDM }(8.5 \%) \\
\text { Foetal: IUGR (13\%), Neonatal jaundice }(60 \%)\end{array}$ & {$[40]$} \\
\hline $\begin{array}{l}\text { Rajalakshmi MS } \\
\text { et al. }\end{array}$ & 2016 & Imphal & $\begin{array}{l}10 \text { with hypothyroidism out } \\
\text { of } 300 \text { women }(3.3 \%)\end{array}$ & $\begin{array}{l}\text { Maternal: Anemia (80\%), Abortion }(3.3 \%) \\
\text { Preeclampsia }(5.5 \%), \text { GDM }(2.7 \%) \\
\text { Foetal: IUGR }(0.7 \%)\end{array}$ & {$[41]$} \\
\hline Present Study & 2016 & Manipal & $\begin{array}{l}79 \text { with hypothyroidism out } \\
\text { of } 2632 \text { women }(3 \%)\end{array}$ & $\begin{array}{l}\text { Gestational Hypertension (3.8\%), GDM (6.3\%), } \\
\text { Placenta praevia (1.3\%), Preterm (7.6\%) } \\
\text { Foetal: IUGR (1.3\%), LBW (3.8\%), Perinatal } \\
\text { Asphyxia (2.5\%), Neonatal hypothyroidism (1.3\%) }\end{array}$ & - \\
\hline
\end{tabular}


Table 7 shows obstetric and perinatal outcome from different studied conducted in India in different parts of the country. It can be seen that there are complications both with respect to mother and baby as a result of subclinical hypothyroidism and this warrants close monitoring of the pregnancy even with fT 4 and fT3 in normal ranges.

Though in our study, the incidence of preterm labour was significantly more than controls ( $7.6 \%$ vs. $1.1 \%)$, it is not appreciably more than the general incidence of preterm labour (11.1\%) [16]. The reported national incidences of hypertensive disorders of pregnancy $(10.08 \%)$ [17], Gestational Diabetes (13.4\%) [18], Anemia complicating pregnancy (50\%) [19], placenta previa (1.01\%) [20], IUGR $(16.8 \%)$ [21], Low Birth Weight (20\%) [22], Birth asphyxia (6\%) [23], are relatively higher, compared to the statistics in maternal subclinical hypothyroidism, meaning that subclinical hypothyroidism with normal free T3 and T4 levels may not significantly contribute to the incidence of above-mentioned complications.

In non-pregnant women, a TSH range of 4 to $5 \mathrm{mIU} / \mathrm{l}$ is considered as an upper limit, however the majority of the studies including American Thyroid Association (2011) suggest that lower range is recommended for the pregnant population as already mentioned earlier. But there are studies who have found a much higher range of TSH levels in pregnancy without any undue effects on mother and baby. TSH data from cohorts of pregnant women without any preexisting thyroid disease have shown higher ranges, for example, upper limit of $4.87 \mathrm{mIU} / \mathrm{l}$ in China [24], $5.00 \mathrm{mIU} / \mathrm{l}$ in India,5.09 $\mathrm{mIU} / \mathrm{l}$ [25] in US [26], and $5.5 \mathrm{mIU} / \mathrm{l}$ in UK [27].

Pushing down the limit to $2.5 \mathrm{mIU} / \mathrm{l}$ may apparently increase the incidence of gestational hypothyroidism as high as $28 \%$ causing undue worry to the obstetrician and apprehension to the patient [28]. There is a strong notion that one should not follow universal guidelines, instead, should depend upon customized ranges based on TSH levels of the local population.

To find the effect of thyroxine replacement for subclinical hypothyroidism in pregnancy, a recent Cochrane Review [15] in the year 2013, analysed the results of four randomised controlled trials critically and it was opined that data is too insufficient to make any recommendations intervention with thyroxine therapy in obstetric practice. Another well-designed study did not observe any significant differences in the study group (232 women who received thyroxine for high TSH and normal T3 and T4 values) and placebo group (264 women who did not receive thyroxine for the same thyroid profile) with regard to preterm delivery, birth weight and child's cognitive function at $3^{\text {rd }}$ year of life [42], They opined that thyroxine intervention is unlikely to provide any measurable benefit if median TSH concentration falls below $3.8 \mathrm{mIU} / \mathrm{l}$. Even in nonpregnant population, treatment with thyroxine has not provided any measurable benefits, such as improvement of lipidemic profile and systemic inflammatory markers and treatment should be started only if TSH concentration is above $10 \mathrm{mIU} / \mathrm{l}$ [43].

Currently National guidelines advocates screening for hypothyroidism for those women who belong to high-risk category (mothers residing iodine deficiency area, obesity, symptoms of thyroid dysfunction or presence of goiter, positive family history, bad obstetric history, previous recurrent miscarriages, preterm delivery, intrauterine demise, preeclampsia-eclampsia, abruptio placentae, treatment with amiodarone or lithium) [44]. The cut-offs are as same recommended by American Thyroid Association. The recommendation states that the pregnant woman should be started on levothyroxine $25 \mu \mathrm{g} /$ day for TSH range of 2.5 to $10 \mathrm{mIU} / \mathrm{l}$ and 50 $\mu \mathrm{g} /$ day if initial TSH is $>10 \mathrm{mIU} / \mathrm{l}$. Postpartum treatment will be continued at recommended doses for those with $\mathrm{TSH}>10 \mathrm{mIU} / \mathrm{l}$. For women with TSH between $2.5-10 \mathrm{mIU} / \mathrm{l}$, treatment should be discontinued after delivery. If this practice is strictly enforced, we are likely to come out with a large interventional data, and the controversy about thyroxine replacement in subclinical hypothyroidism may be authentically solved.

The present study drives home two important points; first using a cut-off of $2.5 \mathrm{mIU} / \mathrm{l}$ is unlikely to identify women at risk of obstetric and perinatal complication, second there is a need for Indian reference for trimester-specific range for TSH which is derived from large pregnant population with euthyroid status (normal free T3 and $\mathrm{T} 4$ levels) corrected for ethnic and regional differences.

\section{CONCLUSION}

The obstetric complications do occur in women with hypothyroidism, but whether they are just associations or random occurrences are yet to be explored. With improved prenatal counselling facilities, one should aim at early detection of maternal hypothyroidism and decide the need for thyroxine replacement according to the situation, which will greatly improve the obstetric and perinatal outcome. In complicated cases, a multidisciplinary team approach, comprising of obstetrician, physician, anaesthetist, paediatrician and endocrinologist, hopefully, will improve pregnancy outcome of those who are affected.

\section{CONFLICT OF INTERESTS}

Declared none

\section{REFERENCES}

1. Renuka P, Akila S, Ebenezer W. Prevalence of metabolic syndrome and its components in women with subclinical hypothyroidism. Asian J Pharm Clin Res 2013;6:82-4.

2. Mannisto T, Vaarasmaki M, Hartikainen AL. Perinatal outcome of children born to mothers with thyroid dysfunction or antibodies: a prospective population-based cohort study. J Clin Endocrinol Metab 2009;94:772-9.

3. So LB, Mandel SJ. Thyroid disorders during pregnancy. Endocrinol Metabol Clin North Am 2006;35:117-36.

4. Smallridge RC, Glinoer D, Hallowell JG, Brent G. Thyroid function inside and outside pregnancy: what do we know and what don't we know? Thyroid 2005;15:54.

5. Sanghvi U, Diwakar KK. Universal newborn screening for congenital hypothyroidism. Indian Pediatr 2008;45:331-2.

6. Päkkilä F, Männistö T, Hartikainen AL. Maternal and child's thyroid function and child's intellect and scholastic performance. Thyroid 2015;25:1363-74.

7. Stagnaro-green A, Abalovich M, Alexander E. Guidelines of the American thyroid association for the diagnosis and management of thyroid disease during pregnancy and postpartum. Thyroid 2011;21:1081-125.

8. Zarghami N, Rohbani-noubar M, Khosrowbeygi A. Thyroid hormones status during pregnancy in normal Iranian women. Indian J Clin Biochem 2005;20:182-5.

9. Yussuf AY, Bhogireddy N, Vulli V, Verma A, Bhaskaran AA. Thyroid stimulating hormones and free thyroxine as an indication of thyroid dysfunction at pathology laboratory of Mnazi Mmoja Hospital, Zanzibar. Asian J Pharm Clin Res 2014:7;67-71.

10. Marwaha RK, Tandon N, Gupta N, Karak AK, Verma K, Kochupillai N. Residual goitre in the post-ionization phase: Iodine status, thiocyanate exposure and autoimmunity. Clin Endocrinol (Oxf) 2003;59:672-81.

11. Das S, Bhansali A, Dutta P, Aggarwal A, Bansal MP, Garg D, et al. Persistence of goitre in the post-iodization phase: micronutrient deficiency or thyroid autoimmunity? Indian J Med Res 2011;133:103-9.

12. Glinoer D, de-Nayer P, Bourdoux P. Regulation of maternal thyroid during pregnancy. J Clin Endocrinol Metab 1990;71:276-87.

13. Ballabio M, Poshyachinda M, Ekins RP. Pregnancy-induced changes in thyroid function: the role of human chorionic gonadotropin as a putative regulator of the maternal thyroid. J Clin Endocrinol Metab 1991;73:824-31.

14. WHO, UNICEF. Reaching optimal iodine nutrition in pregnant and lactating women and young children: a joint statement by WHO and UNICEF. Geneva, World Health Organization; 2007.

15. Reid SM, Middleton P, Cossich MC, Crowther CA, Bain E. Interventions for clinical and subclinical hypothyroidism prepregnancy and during pregnancy. Cochrane Database Syst Rev 2013;CD007752.

16. Blencowe H, Cousens S, Chou D. Born too soon: the global epidemiology of 15 million preterm births. Reprod Health 2013;10 Suppl 1:S2. 
17. Gupte S, Wagh G. Preeclampsia-eclampsia. J Obstet Gynaecol India 2014;64:4-13.

18. Seshiah V, Balaji V, Balaji MS, Sanjeevi CB, Green A. Gestational diabetes mellitus in India. J Assoc Physicians India 2004;52:707-11.

19. Kalaivani K. Prevalence and consequences of anaemia in pregnancy. Indian J Med Res 2009;130:627-33.

20. Hebbar SS, Rai L, Zainab R, Guruvare S, Adiga P, Mundkur A. Influence of placental position on obstetric morbidity in placenta praevia. Int J Reprod Contracept Obstet Gynecol 2014;3:585-91.

21. Pillay P, Janaki S, Manjila C. A Comparative study of gravedo gram and ultrasound in the detection of IUGR. I Obstet Gynaecol India 2012;62:409-12.

22. Bharati P, Pal M, Bandyopadhyay M, Bhakta A, Chakraborty S, Bharati P. Prevalence and causes of low birth weight in India. Malays J Nutr 2011;17:301-13.

23. Babu BVA, Devi SS, Kumar BK. Birth asphyxia,-Incidence and immediate outcome in relation to risk factors and complications. Int J Res Health Sci 2014;2:1064-71.

24. Li C, Shan Z, Mao J. Assessment of thyroid function during firsttrimester pregnancy: what is the rational upper limit of serum TSH during the first trimester in Chinese pregnant women? J Clin Endocrinol Metab 2014;99:73-9.

25. Marwaha RK, Chopra S, Gopalakrishnan S, Sharma B, Kanwar RS, Sastry A, et al. Establishment of erence range for thyroid hormones in normal pregnant Indian women. Br J Obstet Gynaecol 2008;115:602-6.

26. Casey BM, Dashe JS, Spong CY. The perinatal significance of isolated maternal hypothyroxinemia identified in the first half of pregnancy. Obstet Gynecol 2007;109:1129-35.

27. Cotzias C, Wong SJ, Taylor E. A study to establish gestationspecific erence intervals for thyroid function tests in a normal singleton pregnancy. Eur J Obstet Gynecol Reprod Biol 2008; 137:61-6.

28. Negro R, Stagnaro-Green A. Diagnosis and management of subclinical hypothyroidism in pregnancy. $\mathrm{Br}$ Med J 2014;349:g4929.

29. Ajmani SN, Aggarwal D, Bhatia P, Sharma M, Sarabhai V, Paul M. Prevalence of overt and subclinical thyroid dysfunction among pregnant women and its effect on the maternal and fetal outcome. J Obstet Gynaecol India 2014;64:105-10.

30. Aggarwal N, Suri V, Joshi B, Dutta P, Bhansali A, Mukhopadhyay. Prevalence and impact of subclinical hypothyroidism in the pregnancy-prospective study from apex institute of North India. Med Sci 2014;4:404-6.

31. Pavanaganga A, Rekha BR, Sailakshmi MPA, Nagaratnamma. An observational study of subclinical hypothyroidism in pregnancy. Indian J Obstetrics Gynaecol Res 2015;2:255-60.
32. Singh A, Reddy MJ. Prevalence of thyroid dysfunction in pregnancy and its implications. Int J Med Sci Public Health 2015;4:1247-50.

33. Kalpesh K, Alpesh P, Harshid LP. High prevalence of thyroid dysfunction among pregnant women in Ahmedabad City, Gujarat, India. Int J Adv Res 2015;3:676-82.

34. Nirmala C, Jayakumari C, Rajasekharan C, Nandini VR. Maternal outcome of hypothyroidism in pregnancy-a south Indian perspective. Am J Clin Med Res 2014;2:47-50.

35. Sreelakshmi U, Divya JT. Evaluation of effects of subclinical hypothyroidism in pregnancy and its outcome. Int J Sci Res 2015;4:1534-7.

36. Nath J, Duta S. A clinical study on thyroid dysfunction in pregnancy and its effect on the foetomaternal outcome. Int J Sci Res 2015;4:2068-70.

37. Saraladevi R, Nirmala Kumari T, Shreen B, Usha Rani V. Prevalence of thyroid disorder in pregnancy and pregnancy outcome. Int Arch Integrated Med 2016;3:1-11.

38. Patwari M, Talukdar B, Waanbah BD. Study of thyroid profile in pregnancy with perinatal outcome. New Indian J Obgyn 2016;2:73-7.

39. Chunchaiah S, Prasad N, Murali BM, Rupakala BM, Rangaiah N. A prospective observational study of thyroid dysfunctions during pregnancy in a tertiary care hospital. Int J Reprod Contracept Obstet Gynecol 2016;5:3683-9.

40. Patel RD, Deliwala KJ, Shah PT, Singh RK. The fetomaternal outcome of thyroid disorder in pregnancy. Int J Reprod Contracept Obstet Gynecol 2016;5:4466-9.

41. Rajalakshmi MS, Singh AK, Sujit D, Samchetsabam RD. The fetomaternal outcome in maternal hypothyroidism complicating pregnancies at RIMS: a prospective study. Eur J Pharm Med Res 2016;3:452-9.

42. Lazarus JH, Bestwick JP, Channon S, Paradice R, Maina A, Rees $\mathrm{R}$, et al. Antenatal thyroid screening and childhood cognitive function. N Engl J Med 2012;366:493-501.

43. Gupta G, Sharma P, Kumar P, Sharma R. Scope of inflammatory markers in subclinical hypothyroidism. Asian J Pharm Clin Res 2015;8;24-7.

44. National Guidelines for Screening of Hypothyroidism during Pregnancy, Ministry of Health and Family Welfare, Government of India; 2014.

\section{How to cite this article}

- Shripad Hebbar, Sahan Kumar, Sapna Amin, Sneha Doizode. Subclinical hypothyroidism in pregnancy; is there a need for pharmacological intervention? Int J Pharm Pharm Sci 2017;9(3):186-191. 